\title{
The Influence of Individual Caring and Organizational Trust on Organizational Commitment of Private LPTK Lecturers in Medan City
}

\author{
Khairtati Purnama Nasution ${ }^{1}$, Zainuddin ${ }^{2}$, Arif Rahman ${ }^{3}$ \\ ${ }^{1,2,3}$ Universitas Negeri Medan, Indonesia \\ khairtatinasution@gmail.com
}

\begin{abstract}
This study aims to reveal the influence of individual caring and organizational trust on organizational commitment of private LPTK lecturers in Medan city. This research design is classified as ex post facto research which has a causal relationship using a quantitative approThis research was conducted at private LPTKs throughout the city of Medan. This study was planned for 6 months. The population of this research is all lecturers who work in LPTK in Medan City. Based on data from each LPTK in Medan City, it was found that an overall population of 489 lecturersach. This research design uses a survey method. The data obtained from the measurement results were analyzed descriptively and inferentially. The stages in data analysis to be carried out in this study are descriptive analysis and inferential analysis. The results reveal that: 1. there is a significant effect of individual Carring variance on organizational trust. 2. there is a significant effect of Organizational Trust on Organizational Commitment.
\end{abstract}

Keywords

individual caring;

organizational

commitment; private

LPTK lectures

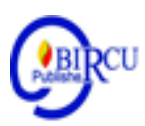

\section{Introduction}

Improving the quality of human resources is one component of achieving development goals. One vehicle for improving the quality of human resources is education. The quality of human resources will continue to increase when accompanied by good quality education. Therefore education must be implemented systematically and directed based on interests that refer to advances in science and technology and based on faith and devotion. However, the fact is that the quality of education in Indonesia is still lower than the quality of education in other countries such as Malaysia and Singapore (Human Capital Report, 2015: 16).

Efforts to improve the quality of education have been carried out by the government through various programs, such as lecturer certification for private lecturers with the aim, among other things, that lecturers' commitment to serve in the relevant tertiary institution can be maintained.

As the front guard in the educational process, lecturers have a very important role. Lecturers play a broad role in intensifying the learning process, and lecturers need to adapt to the demands of the bureaucracy, pressure, expectations and control of lecturers about what and how much they have to do in their assignments (Amstrong, 2003). Lecturer commitment is also related to lecturer performance and their ability to innovate, integrate new ideas into the learning process, attendance, turnover, and have an important influence on student achievement (Leininger:1993); Tanner: 1990). Lecturers who are committed to the organization tend to have high performance, will always appear to be present, behave 
positively, and show good performance. (Slocum, 2009; Colquitt et al, 2006; Robbin, 2006). But it seems that these hopes have not shown satisfactory results. The results of preliminary studies on several lecturers at the Private Higher Education Institute in Medan show that the turnover rate is due to relatively high turnover. Every year there are several lecturers who quit or new lecturers who come to work with less than one year of work. In addition, it was also conveyed that if they have the opportunity to get a better job, they will voluntarily resign from the organization. Various reasons were presented in this regard; such as opportunities and lecturer development systems to improve work ability are almost non-existent, opportunities to innovate and self-actualize even though some lecturers feel capable,

Besides that, most of the lecturers have not shown high commitment in carrying out the tri darma of higher education, especially in the fields of research and community service. There are still many private LPTK lecturers who are reluctant to make research and dedication for various reasons. This fact shows a problem with the commitment of lecturers, especially private LPTK lecturers.

This condition is exacerbated by the communication pattern that is built showing an unbalanced relationship, where what happens is one-way communication from top to bottom, namely from the foundation as the owner to the lecturer as an employee. This, for example, occurs in the conditions of selecting the education manager as manager, and the compensation system in the form of service fees that is not transparent and standardized. This phenomenon is part of the picture of the low level of individual commitment to teacher training organizations such as the LPTK.

In the LPTK organization, this dilemma becomes more severe, apart from the various quality standards that must be prepared to achieve quality learning, the philosophical foundation of the teaching profession is also a very important basis to be considered in shaping the character and behavior of students as prospective professional staff. If traced based on an organizational behavior approach, especially in teacher education organizations, there are various humanistic values that become philosophical and underlie how a teacher as a profession behaves.

The study of organizational commitment is an important undertaking because this concept is considered to be directly related to organizational strength, stability and performance. Organizational commitment has an important place in the study of organizational behavior. This is because some research results have found a relationship between organizational commitment and attitudes and behavior at work (Porter et al., 1974, 1976; Koch and Steers, 1978; Angle and Perry, 1981), organizational performance (Angel, 1981; Riketta, 2002) and organizational effectiveness (Laschinger, 2001; Miller, 1978). Furthermore, Batemen and Strasser (1984) state that the reasons for studying organizational commitment are related to (a) employee behavior and performance effectiveness, (b) job satisfaction, (c) job and role characteristics, such as responsibilities and (d) personal characteristics of employees such as age, years of service. A person's commitment to their organization is generally shown in the form of attitudes and work results from that person (Gardner, 2002). Someone who is committed to his organization will always appear present, behave positively, and show good performance (Slocum, 2009; Colquitt et al, 2006; Robbin, 2006).

Whereas someone who has low commitment to the organization will show poor work behavior, namely by showing various unproductive behaviors (withdrawal behavior). Research result Kigershows the relationship between organizational commitment and withdrawal behavior inversely proportional; where individuals with high organizational 
commitment will have low withdrawal behavior, and vice versa. A survey of 500 companies revealed that at most $25 \%$ of organizations feel confident in the capabilities of their staff. Robbins' research also explains that employees who are committed to the organization where they work are characterized by good work behavior (productivity), low absenteeism (absence), and low work turnover (turnover). In line with this Colquit, LePine, Wesson also explained that organizational commitment is needed to ensure that all members of the organization understand well their duties and responsibilities to the organization.

The results of Kibeon L, Julie JS, and Natalie J's research on the relationship between organizational rewards and organizational commitment, the results lead to three behaviors, namely: (1) the ability to identify individual goals with organizational goals, (2) feelings to be involved with tasks, tasks in the organization, and (3) feelings to be loyal to the organization. On the other hand, research indicates that employees' low commitment to the organization can lead to a decrease in organizational effectiveness because employees will tend not to perform well, only do routine work, without innovation, and tend to be easier to accept other jobs. If this happens, the organization will incur high costs for employee turnover or turnover. In addition to, Organizational commitment will reduce turnover, which means that the longer the employee is in the organization, the better their work ability will be, and good workability will require less supervision. Monitoring that is direct and inflexible can be time-consuming and costly. In addition, commitment from employees is reflected in the value and importance of integrating individual and organizational goals. Employees will think about their goals and organizational goals in a personal pattern. Commitment from employees is reflected in the value and importance of integrating individual and organizational goals. Employees will think about their goals and organizational goals in a personal pattern. Commitment from employees is reflected in the value and importance of integrating individual and organizational goals. Employees will think about their goals and organizational goals in a personal pattern.

Commitment is considered an investment in personal resources, has long been associated with a person's professional characteristics. A study conducted by Laurel and Goulet, shows that there are differences in commitment between profit organizations, social organizations and public organizations. Organizational commitment to profit-oriented organizations ranks at the top, followed by social organizations and the lowest occurs in public organizations (Laurel and Goulet, 2006). These findings indicate that commitment is something important and complicated. The difference in commitment between the three types of organizations raises the assumption that organizational commitment is formed from various factors, both individual, organizational and environmental. Therefore, so that the commitment of the lecturer organization can be maintained properly,

Conceptually, commitment can be linked to research conducted in the 1970s by Kanter (1974), Mowday, Steers and Porter (1979) on organizational commitment. Someone is considered to have a commitment to the social context in which they work, or according to Kanter (1974) is described as a 'social system'. However, the overarching assumption states that commitment does not reflect a single dimension, but has many dimensions (Hari, 2000, 2004; Nias 1981, 1996, Tyree, 1996). Thus the commitment of lecturers can be analyzed, by looking at their attitudes towards: (1) universities or organizations (Graham, 1996; Huber, 1999; Louis, 1998; Tsui \& Cheng, 1999), (2) students (Bilken, 1995; Nias , 1981; Tyree, 1996; Yong, 1999), (3) Career (Nias, 1981; Tyree, 1996; Wood, 1981; Yong, 1999), (4) professional knowledge (Nias, 1981; Tyree, 1996; Wood, 1981), (5) Profession as a lecturer (Hari, 2000, 2004; Tyree, 1996). 
Commitment does not appear automatically when someone becomes a member of an organization. Commitment is an attitude that appears based on rational considerations (Webb, RJ, 2005: 77). Organizational commitment arises as a result of job satisfaction (Robbins, 2007; Colquitt, 2009; Luthan, 2005). Robbins, Slocum \& Hellriegel explained that in organization, individual attitudes can be in the form of affective, cognitive, or behavior. As things that will affect how individuals behave, attitude is something important. Attitudes related to how individuals work as employees, explained Robbins, relate to three things, namely: job satisfaction, job involvement and organizational commitment. This relationship is supported by several moderator variables; such as the importance of the attitude, specificity of the attitude, accessibility of the attitude, social pressure (social pressures on the individual), and direct experience with the attitude.

Based on the explanation above, it can be seen that individual attitudes towards the organization are one of the factors that will influence the formation of individual commitment to the organization. Affective individual attitudes; consists of components of the individual's ability to feel something (people, events, ideas, or objects), feelings, moods, and emotions. Cognitive attitude, consisting of components of thoughts, opinions, knowledge, or information about the individual. Meanwhile, attitudes are in the form of behavior; consists of components about the tendency to obey something, either something good or something bad. Thus commitment is the output of the influence of various organizational behavior factors, such as: individual factors, group factors, and organizational factors. Likewise with Aven Parker \& McEvoy; Mathieu \& Zajac, they believe that the factors that influence organizational commitment consist of individual personal characteristics, organizational characteristics, and organizational experiences.

This dispositional variable has a stronger relationship with organizational commitment, because of the differences in the experiences of each member in the organization. Meanwhile, organizational experience includes the satisfaction and motivation of organizational members while in the organization, their role in the organization, and the relationship between organizational members and their supervisors or leaders. This opinion is in line with Colquit, LePine, and Wesson that stated organizational commitment is influenced by several factors, namely: organizational mechanism factors, group mechanism factors, and individual characteristic factors. These three factors will then influence the individual mechanism factor until finally it will affect work behavior (job performance) and organizational commitment. Organizational mechanism factors consist of organizational culture and organizational structure. The group mechanism factor consists of the behavior and leadership style, the influence and strength of the leader, the processes that take place in the group, and group characteristics. Furthermore, individual characteristic factors consist of cultural and personality values, and abilities. While the individual mechanism factors consist of job satisfaction, stress.

Based on this, researchers need to carry out scientific studies by conducting studies and analyzing variables that are likely to determine the commitment of lecturers in educational organizations, especially Teacher Higher Education by limiting research to several variables, which consist of: individual caring behavior, organizational caring behavior, trust, and justice.

Based on the background of the problem as stated above, the research aims to determine the effect of variables:

1. Caring individuals against trust organizations of private LPTKs in North Sumatra

2. Trust organization to the commitment of private LPTK organizations in North Sumatra. 


\section{Review of Literatures}

\subsection{Organizational Commitment \\ a. Definition of Organizational Commitment}

There are two approaches in formulating the definition of commitment in organization.

The first involves an attempt to illustrate that commitment can appear in various forms, that is, the meaning of commitment explains the different relationships between organizational members and other entities. The second involves trying to separate among the various entities to which individuals develop into commitments. These two approaches are not compatible but can explain the definition of commitment, how the process of development is and what the implications are for individuals and organizations.

Prior to the emergence of these two approaches, there was another approach that appeared and took longer to use, namely differentiation based on attitudinal commitment (approach based on attitudes) and behavioral commitment (approach based on behavior). This more traditional distinction has implications not only for the definition and measurement of commitment, but also for the approaches used in various studies of development and consequences of commitment.

Mowday et al in Meyer \& Allen explained that the attitudinal commitment approach focuses on the process of how a person starts thinking about his relationship in the organization or determines his attitude towards the organization. This can be considered as a mindset in which individuals think about the extent to which their own values and goals are in accordance with the organization in which they are located. Meanwhile, behavioral commitment is related to the process by which individuals feel attached to certain organizations and how they can overcome any problems they face.

Research on attitudinal commitment involves measuring commitment (as an attitude or mindset), along with other variables that are considered to be causes, or consequences of commitment. This study aims to show that based on the perspective of the organization a strong commitment causes the behavior of members of the organization as expected. For example, organizational members rarely attend (absent) and turnover to another organization is lower (turn over), and productivity is higher. The second objective shows what individual characteristics and circumstances affect the development of high organizational commitment.

In behavioral commitment, members are seen to be committed to certain behaviors, rather than to an entity alone. Attitude or behavior that develops is a consequence of commitment to a behavior. For example, members of an organization who are committed to their organization may develop a more positive outlook on the organization, be consistent with their behavior to avoid cognitive dissonance or to develop positive self-perceptions. The purpose of this study is to determine what conditions make individuals committed to their organization.

Commitment is considered a psychological state, however this can develop retrospectively (as a justification for the ongoing behavior) as proposed by the behavioral approach, as well as prospectively (based on perceptions of current or future conditions in the organization) as stated in the attitudinal approach. Meyer and Allen formulated a definition of organizational commitment as a psychological construct which is a characteristic of the relationship between organizational members and the organization and has implications for individual decisions to continue their membership in organizations. Based on this definition, members who are committed to their organization will be more able to survive as part of the organization than members who are not committed to the organization. 
Armstrong stated that commitment is love and loyalty. It is further explained that commitment consists of three components; which consists of a union with the goals and values of the organization, a desire to stay together and be in the organization, and a willingness to work hard on behalf of the organization. This shows the unification between individuals as organizational personnel with organizational goals and values. This situation means that all members of the organization must unite the goals of each individual with the goals of the organization. All members of the organization must apply the values that exist in the organization.

In line with research from Baron and Greenberg, it is stated that organizational commitment means a strong individual acceptance of the goals and values of the organization, where individuals will try and work and have a strong desire to remain in the company. Based on various definitions of commitment to the organization, it can be argued that commitment to the organization reflects three main dimensions, namely commitment reflecting the affective orientation of the organization, consideration of losses if leaving the organization, and the moral burden of continuing to exist in the organization.

Over time, organizational commitment will get stronger for several reasons, such as: (1) each individual experiences a deeper development in their organization and for their employees, they spend more time for employees, (2) seniority will bring benefits that will be used for a more positive development of behavior at work, (3) opportunities in work which will decrease with age, because the stronger employees will be in their organization.

The desire to stay together and be in the organization can be an analogy like pa partner who expresses a joint commitment means the desire to remain together under any circumstances. Likewise in organizations, employees who are declared committed are those who wish to remain in the organization. If there is still the desire to find another organization, it means that their commitment is in doubt. Meanwhile, the willingness to work hard on behalf of the organization can be described by people who are committed to the organization, so that person will work as well as possible wherever he is placed.

Based on the opinion of these experts, it can be concluded that commitment psychological construct forms that are characteristic of the relationship between organizational members and their organizations and have implications for individual decisions to continue their membership in organizations.

\section{b. Types of Commitment in the Organization}

Meyer and Allen, Colquit, LePine, and Wesson formulate three types of commitment in organization, namely: affective, continuance, and normative commitment. These three things are more properly expressed as a life or dimension of organizational commitment, than types of organizational commitment. This is because the relationship between the members of the organization and the organization reflects the different degrees of the three dimensions.

Affective commitment relating to the emotional relationship of members to the organization, identification with the organization, and involvement of members with activities in the organization. The feeling of actually getting what he wants is a major factor (want). They feel that the organization has the same goals and values as it hopes for.

Continuance commitment related to the awareness that organizational members will experience losses if they leave the organization. The main basis for individuals with a continuance commitment that individuals need their work (need). This type of commitment tends to be passive, where the staff will do something solely based on the rewards they will get. Needs that family; children or wife who attends school, live, or work within an affordable distance are also reasons for individuals to commit. 
Normative commitment describes a feeling of being attached to staying in the organization. Organizational members with high normative commitment will continue to be members of the organization because they feel they should be in the organization (ought). In addition, the feeling that the organization has provided an opportunity not to leave their job, even though the situation requires leaving, is a strong reason for individuals not to leave their job.

The three types of organizational commitment can occur or relate to various things, such as dealing with companies, top-level managerial, departments, leaders, work teams, or with work colleagues. The following is a schematic of the direction of the overall organizational commitment.

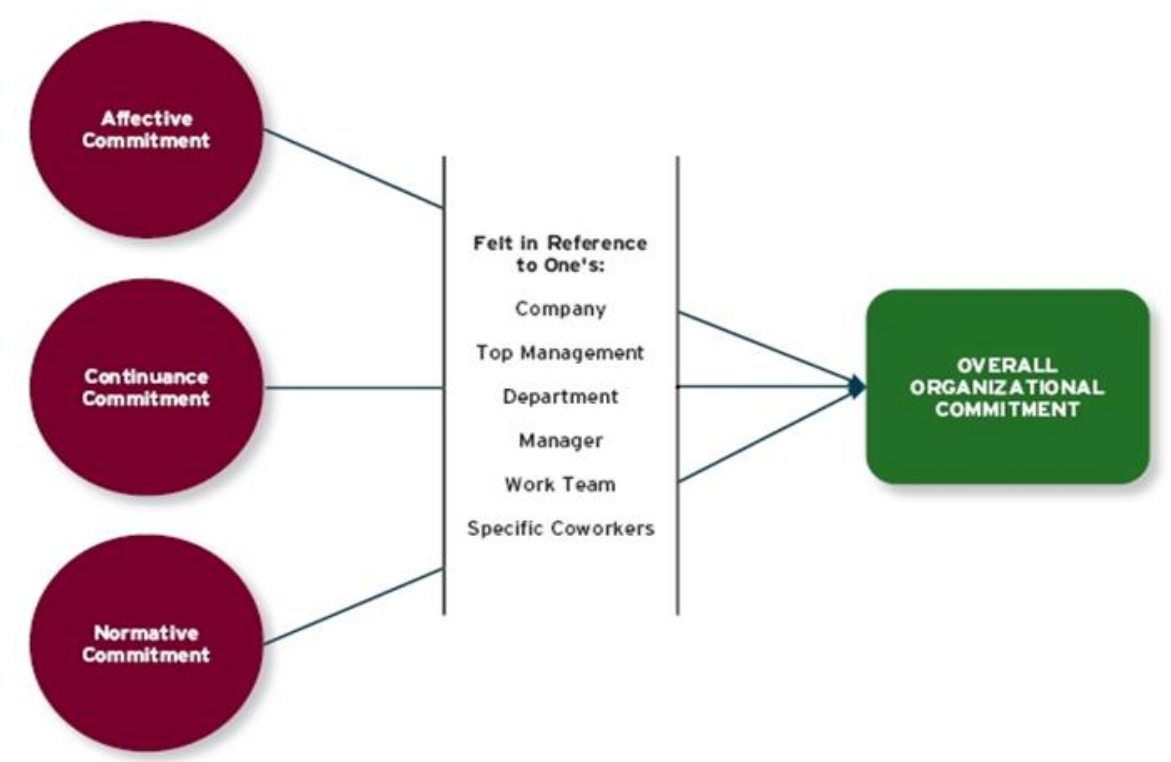

Source: Jason A Colquitt, Jeffery A LePine, Michael J Wesson, Organizational Behavior. Improving Performance and Commitment in the Workplace (Singapore: McGraw-Hill, 2009), p. 69.

\subsection{Caring Individual}

Since the beginning of practice and the educational profession has been concerned with the concept of caring. Nightingale, as the initiator of educational practice, has from the very beginning established a structure of educational knowledge that is useful for the healing of students through a caring-healing model. Then Watson (1985) gave special emphasis to the ideal concept of caring in his declaration which explained that caring is a very important moral underlying educational science and practice related to how to improve and maintain human dignity.

Nightingale (1959) has described caring as the core or essence of educational science and the concept of caring is the basis for the philosophy of educational practice, which will also affect educational organizations, educational processes and educational research.

Watson (1985), Swanson (1991) and Leininger (1993) has developed the literature on caring theory over the years. Watson put forward the theory of caring in his first book Philosophy and Science of Caring in 1979 and continuously conducts research and writes on the grand theory of caring. Watson describes caring in the context of educational science as a commitment to care as well as the value of caring, caring for knowledge, caring about consequences and intervention. 
Caring is the essences of the accountability of the educator-student relationship, where educators help participate, help gain knowledge and improve learning outcomes. Caring is the essence of education which is the focus and central of educational practice. Caring in education is very basic. Caring is the "heart" of the profession, meaning that it is a fundamental component of the unique and central focus of education. Although the word caring has been used in general, there is no universal definition and conceptualization of caring itself. There are at least five perspectives or categories regarding caring, namely: caring as a human nature, caring as a therapeutic intervention, and caring as a form of affection.

Caring It is difficult to define because it has multiple meanings: as a noun or a verb, as something that can be felt, as an attitude or behavior. Watson defines educator caring behavior as a behavior that includes: listening attentively, entertainment, honesty, patience, responsibility, and providing information.

Based on the opinion of these experts, it can be concluded that caring a personal behavior which includes: listening to others attentively, entertainment, honesty, patience, responsibility, providing adequate information so that others can make decisions.

\subsection{Trust Organization (Trust in Organization)}

Colquit, LePine, and Wesson define that trust is: Willingness to be vulnerable to an authority based on positive expectations about the authority's actions and intentions. The description of this definition explains that when someone believes (trust) something, that person has a desire to submit to the authority of the ruler. This is a risky choice for disappointment. There are two important things that can be seen from this phenomenon, namely trust and risk. Being sensitive and submitting to comply with other authorities that do not come from one is a risk; while the willingness to voluntarily take the risk is trust. However, the emergence of trust in someone, of course, is based on certain reasons. The definition above illustrates that a trust will be formed if it is based on an assessment of how the authority is determined to act in certain situations.

Mayer, Davis and Schoorman (1991) explained that trust is the willingness of certain parties to submit to collaboration with other parties and vice versa, based on the expectation that each party will take actions that are beneficial to the other party. Meanwhile, Carnevale defines trust from the point of view of public organizations, which explains that trust is an individual expression of his belief and belief that a person or institution will act fairly, reliably, ethically, competently, and not threaten.

Based on the opinion of these experts, it can be concluded that trust is the willingness of certain parties (individuals, institutions, etc.) to submit to collaboration with other parties and vice versa, on the basis of the expectation that each party will take actions that are beneficial to the other party.

\subsection{Framework of Thinking}

\section{a. The Influence of Individual Caring on Organizational Trust}

Based on the organizational behavior approach, especially in educational education organizations, there are various humanistic values that become the philosophy and underlie how an educator as a profession behaves. One of these humanistic values is caring behavior. Based on the proposition of organizational behavior from Colquit, LePine, Wesson explained that in one of the individual characteristics there are cultural values that will influence the individual mechanism, one of which is trust.

Trust is the result of an interaction. Personally, individuals can show that they can be trusted through the behavior they display. But from an organizational viewpoint, trust is built 
through a series of day-to-day operational principles. Trust built from the habit of behaving in accordance with agreed terms which contain shared beliefs about how to carry out relationships in work.

When trust is not built and lost, what will happen is that members of the organization will leave the organization. The main reason an individual as an employee leaves the organization is because they don't trust their leader and feel that the organization they work for is run by people who cannot afford it.

Based on the description above, it can be assumed that educational education organizations by caring individuals will be more trustworthy because they integrate humanistic values (humanistic) into interpersonal relationships both formally and informally in running the organizational system.

\section{b. The Effect of Organizational Trust on Organizational Commitment}

Trust (Trust) is the willingness of certain parties to submit to collaboration with other parties and vice versa, on the basis of the expectation that each party will take actions that are beneficial to the other party. Based on the point of view of public organizations, it is explained that trust is an individual expression of his belief and belief that a person or institution will act fairly, reliably, ethically, competently, and not threatening.

When a person believes in something, that person has a desire to submit to the ruling authority. This is a risky choice to possibly lead to disappointment, because you have trusted the other party completely. There are two important things that can be seen from this phenomenon, namely trust and risk. Being sensitive and submitting to obey other authorities that do not come from one self is a risk; while the willingness to voluntarily take the risk is trust. However, the emergence of trust in someone, of course based on certain reasons, is not formed automatically. Trust will be formed if it is based on an assessment of how the authority is determined to act in certain situations which can be assessed for its suitability and reasonableness.

Kethics of trust is not built and lost, so what will happen is that members of the organization will leave the organization. Statistically, the main reason an individual leaves an organization is because they don't trust their leader and feel that the organization they work for is run by incapacitated people. This shows that, when organizational personnel no longer trust the organization for whatever reason, especially with regard to the ability and suitability of the leadership's actions with the applicable system, the commitment will immediately disappear.

A commitment must arise from the deepest heart of a person in carrying out his function in the organization. If every individual in the organization has a great commitment to do the best for their work, then this is a big asset for the Higher Education organization in realizing organizational goals.

\section{Research Methods}

This research design is classified as ex post facto research which has a causal relationship using a quantitative approach. This research design uses a survey method, where survey research is included in the explanatory research category because this study aims to explain the causal relationship with hypothesis testing. Hypothesis testing in this study will be carried out by path analysis, to identify the direct or indirect effect of a set of causal variables (exogenous variables) on a set of consequential variables (endogenous variables), 
using the correlated path model because in this model exogenous variables are taken into account.

This research conducted at private LPTKs throughout the city of Medan. This study was planned for 6 months. The population of this research is all lecturers who work in LPTK in Medan City. Based on data from each LPTK in Medan City, it was found that an overall population of 489 lecturers.

Based on the number and description of the characteristics of the population there are several differences in the number based on certain criteria (strata), so that it cannot be assumed to be homogeneous. Based on this, to determine the number of samples used a sampling method that can describe the proportions of each stratum, namely stratified random sampling. By considering the proportion of each stratum, the member of the population with a sample size is of 148 respondents. The data collection technique used was a survey technique using a questionnaire. The questionnaire contains questions or statements developed based on a theoretical review, and is submitted in writing to respondents as research samples to obtain answers or responses related to various experiences, perceptions, and problems faced regarding the influence of individual caring, organizational caring, trust, and organizational justice on organizational commitment. The data obtained from the measurement results were analyzed descriptively and inferentially. The stages in data analysis to be carried out in this study are descriptive analysis and inferential analysis.

\section{Discussion}

\subsection{Description of Research Results}

The results of this study include five variables, namely (1) Individual Caring Behavior, (2) Organizational Trust, and (3) Organizational Commitment. The results of the descriptive analysis obtained the average score, median, mode, minimum score, maximum score, variance and standard deviation. To make it easier to understand the research data, the data is also presented in the form of frequency distribution and histogram graphs. The summary of the descriptive analysis results is presented in table 1.

Table 1. Descriptive Statistical Summary of Research Data

\begin{tabular}{|l|r|r|r|}
\hline \multirow{2}{*}{\multicolumn{1}{c|}{ Analysis }} & \multicolumn{3}{c|}{ Variable } \\
\cline { 2 - 4 } & X1 & \multicolumn{1}{c|}{ X2 } & \multicolumn{1}{c|}{ X3 } \\
\hline Lots of data (N) & 148 & 148 & 148 \\
\hline Minimum Score & 53 & 45 & 55 \\
\hline Maximum Score & 87 & 84 & 93 \\
\hline Range & 34 & 39 & 38 \\
\hline Lots of interval classes & 8.16 & 8.16 & 8.16 \\
\hline Interval & 4.17 & 4.78 & 4.66 \\
\hline Average & 67.10 & 60.14 & 75.10 \\
\hline Median & 66.5 & 59 & 75 \\
\hline Mode & 61 & 61 & 74 \\
\hline Standard Deviation & 6.20 & 7.68 & 7.17 \\
\hline Variance & 38.40 & 58.95 & 51.41 \\
\hline Ideal minimum score & 24 & 45 & 55 \\
\hline Ideal maximum score & 96 & 84 & 93 \\
\hline
\end{tabular}




\begin{tabular}{|l|r|r|r|} 
Ideal average & 60 & 64.5 & 74 \\
\hline $\begin{array}{l}\text { Standard Deviation is } \\
\text { ideal }\end{array}$ & 12.00 & 6.50 & 6.33 \\
\hline Item number is valid & 24 & 21 & 25 \\
\hline
\end{tabular}

Information:

X1: Caring Individual

$\mathrm{X} 2$ : Trust Organization

X3: Organizational Commitment

\subsection{Research Hypothesis Testing}

\section{Hypothesis 1}

$$
\begin{aligned}
& \mathrm{H} 0: \rho_{3.1}=0 \\
& \mathrm{H} 1: \rho_{3.1}>0
\end{aligned}
$$

The estimation results show that the $\mathrm{P}$ value for the Carrign Individu path coefficient to organizational trust $\left(\rho_{31}\right)$ is 0.040 , which is smaller than the $\alpha$ value. Thus it can be said that there is a significant effect of individual Carring variance on organizational trust, in other words $\mathrm{Ho}$ is rejected and $\mathrm{Ha}$ is accepted.

2. Hypothesis 2

$\mathrm{H} 0: \rho_{5.3}=0$

$\mathrm{H} 1: \rho_{5.3}>0$

The estimation results show that the $\mathrm{P}$ value for the path coefficient of Organizational Trust to Organizational Commitment $\left(\rho_{52}\right)$ is 0.028 less than the value of $\alpha(0.05)$. Thus it can be said that there is a significant effect of Organizational Trust on Organizational Commitment, in other words $\mathrm{Ho}$ is rejected and $\mathrm{Ha}$ is accepted The following is a summary of the results of the path analysis.

Table 2. Results of the Path Analysis

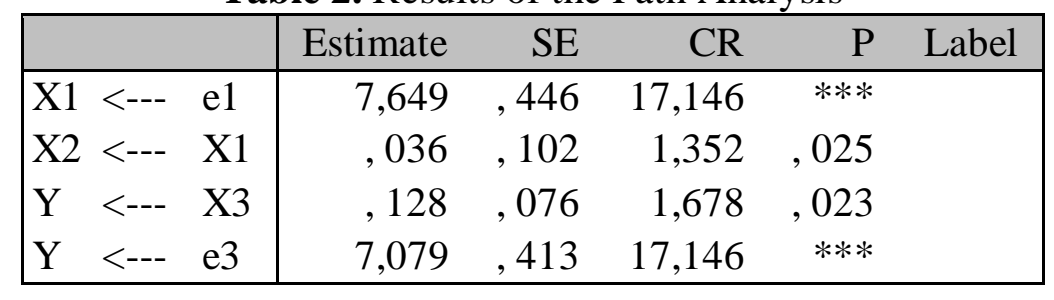

Based on the analysis, it is known that the path coefficient has a $\mathrm{P}$ value $<0.05$, so it can be concluded that all pathways are significant. Visually, the results of the second stage path analysis are as follows:

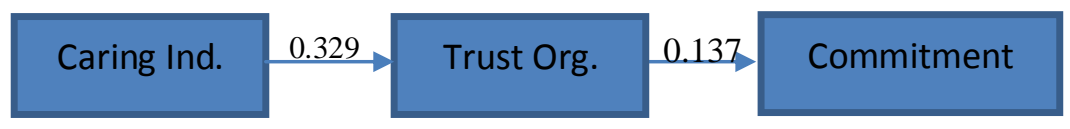

Influence individual caring to organizational trust is empirically proven to be significant in both the stage one and stage two model tests. The amount of individual caring contribution to organizational trust is $32 \%$ while the remaining $68 \%$ is influenced by other factors. This fact proves that the theoretical model of the effect of individual caring on trust is in accordance with the data. These findings prove that when a person has a good individual 
caring, it will encourage the individual to have a positive perception. This positive perception will be reflected in positive behavior, such as the emergence of trust in the organization. In context organization, trust make peer relationships or organizational communication become regular, and through trust make the relationship between superiors and subordinates vertically and horizontally among staff in the organizational environment to run smoothly. Trust makes delegation workwell and trust also makes communication and implementation of knowledge sharing smooth and optimal.

Building organizational trust is not easy; there are four components to pay attention to include pleasant behavior, clear planning, and appropriate incentives. Trust between the leader and his employees are a prerequisite for successful teamwork. Leaders must believe that, given sufficient time, employees will support the changes if needed to facilitate teamwork. Employees must believe that the leader really wants to know what they think.

Trust is the result of an interaction. Personally, individuals can show that they can be trusted through the behavior they display. But from an organizational viewpoint, trust is built through a series of day-to-day operational principles. Trust built from the habit of behaving in accordance with agreed terms that contain shared beliefs about how to do business. One of the individual behaviors that can grow trust is individual caring.

The influence of organizational trust variables on organizational commitment is $13.7 \%$, while the rest is influenced by other factors outside the model. These findings indicate that trust is one of the factors that can increase a person's commitment, the higher the trust, the higher the commitment. A person with a high level of trust tends to be able to show good behavior in the workplace. The direct effect of organizational trust on commitment supports the previous theory which states that there is a significant influence or relationship between trust and commitment. Research conducted by Juan A. Moreno, Mathieu (1990) stated that there is a significant relationship between trust and commitment.

\section{Conclusion}

Influence individual caring to organizational trust is empirically proven to be significant in both the stage one and stage two model tests. This fact proves that the theoretical model of the effect of individual caring on trust is in accordance with the data. These findings prove that when a person has a good individual caring, it will encourage the individual to have a positive perception. This positive perception will be reflected in positive behavior, such as the emergence of trust in the organization. The influence of organizational trust variables on organizational commitment is very significant, while the rest is influenced by other factors outside the model. These findings indicate that trust is one of the factors that can increase a person's commitment, the higher the trust, the higher the commitment.

\section{References}

Amstrong, Michael. (2003). Manging People: A Practical Guide for Line Managers. London: Kogan Page Limited.

Colquit, J.A., LePine, J.A., and Wesson, M.J. (2009). Organizational Behavior. Improving Performance and Commitment in the Workplace. Singapore: McGraw-Hill.

Galford, R. (2011). The Trusted Leader, a Management Forum Series Presentation. www.executiveforum.com.

George, Jennifer, and Gareth, R.J. (2005). Understanding and Managing Organizational Behaviour. (Fifth Edition). Upper Saddle River: Pearson Prentice Hall. 
Gibson, et al. (2009). Organizations: Behavior, Structure, Processes. (Thirteenth Edition). Singapore: The Mc Graw-Hill Companies.

Hasmayni, B. The Difference of Academic Procrastination between Students Who Are Active and Not Active in Organizations Student Activity Units in the Faculty of Psychology, University of Medan Area. Britain International of Linguistics, Arts andEducation(BIoLAE) Journal ISSN: 2685-4813 (Online), 2685-4805 (Print) Vol. 2 (1): 411-421.

Ivancevich, J.M., Konopaske, R., and Matteson, M.T. (2005). Perilaku dan Manajemen Organisasi. (Jilid 1). Jakarta: Penerbit Erlangga.

Leininger, Madeline. (1993). "Culture Care Theory: The Comparative Global Theory toAdvance Human Care Nursing Knowledge and Practice". In A Global Agenda for Caring. 15-2518.

Lunenburg, F.C., and Ornstein, A.C. Educational Administrasi, Concepts and Practice. (Thidr Edition). Belmont: Wadsworth.

Lussier, R.N. (1997). Management: Concepts, Applications, Skill Development. Ohio: Western College Publishing.

Luthans, F. (1997). Perilaku Organisasi. (Edisi Kesepuluh). Alih Bahasa: Vivin Andika Yuwono, dkk. Yogyakarta: Andi.

Mathieu, J. E., and Zajac, D.M. (1990). A review and meta analysis of the antecedents, correlates, consequences of organizational commitment. Psychological Bulletin 108. 171-194.

Mayeroff, M. (1971). On Caring, Harper and Row. New York: Pearson Education.

Meyer, J. P., and Allen, J. (1991). Commitment in the Worplace Theory Research and Application. California: Sage Publications.

Mowday, R. T., Porter, L. W., and Steeras, R. (1982). Organizational linkages : the psychology of commitment, absenteeism, and turnover. San Diego, California: Academic Press.

Mursyidi, et.al. (2019). The Effort of Islamic Boarding School Leaders'to Improve the Potential of Students in Reading Arabic Books (A Study in Dayah Raudhatun Hasanah Namploh Manyang, Samalanga Sub-District, Bireuen District). Britain International of Linguistics, Arts and Education (BIoLAE) Journal Vol. 1 (2): 232-241.

Nightingale, Florance. (1959). Notes on Nursing. Philadelphia: Lippincott.

Noddings, Nel. (1984). Caring A Feminine Approach to Ethics \& Moral Education. Berkeley: University of California Press.

Pasaribu. (2011). "Trust" dan pengaruhnya pada "Knowledge Sharing". (http://www.waspada.co.id).

Robbins, S. P. (2003). Organizational Behavior. (10 ${ }^{\text {th }}$ ed). New Jersey: Prentice Hall.

Robbins, S. P., and Judge, T.A. (2007). Perilaku Organisasi. Jakarta: Salemba Medika.

Robbins, S.P., and Coulter, M. (2007). Management. New Jersey: Pearson Education.

Rodgers, B.L., and Knafl, K.A. (1993). Concept Development in Nursing: Foundation, Techniques, and Application. Philadelphia: W.B. Saunders Company.

Scotto, C. (2003). “A New View of Caring”. Journal of Nursing Education, 42, (7), 289-291.

Slocum \& Hellriegel. (2009). Principles of Organizational Behavior. South-Western: a Part of Cengage Learning.

Sulaiman, Khamidi, A., Mintarto, E. 2020. The Evaluation of Athletic Extracurricular Management of Dr. Soetomo and Jalan Jawa Junior High School in Surabaya. Budapest International Research and Critics in Linguistics and Education (BirLE) Journal Vol. 3 (1): 11-19. 
Swanson, Kristen. (1991). "Empirical Development of a Middle Range Theory of Caring". Nursing Research, 40 (3), 161-166.

Tanner, Christine, A. (1990). "Reflections on the Curriculum Revolution". Journal of Nursing Education 29 (7), 295-299.

Watson, Jean. (1985). Nursing: Human Science and Human Care, A Theory of Nursing (Norwalk: Appleton-Century-Crofts.

Watson. (1988). Nursing: Human Science and Human Care. A Theory of Nursing. (2 ${ }^{\text {nd }}$. ed). New York: National League for Nursing. 